Bioscientia Medicina: Journal of Biomedicine \& Translational Research

Journal Homepage: www.bioscmed.com

\title{
Risk Factors of Vesicovaginalis Fistule in Obstetric and Gynecologic Division of Dr. Mohammad Hoesin General Hospital in 2018-2020
}

\author{
Nabila Istighfarin ${ }^{1}$, Hadrians Kesuma Putra ${ }^{2}$, Eka Handayani Oktharina ${ }^{2}$, Ratih Krisna ${ }^{2}$, Septi \\ Purnamasari ${ }^{3}$ \\ ${ }^{1}$ Medical Education Study Program, Faculty of Medicine, Universitas Sriwijaya, Palembang, Indonesia \\ ${ }^{2}$ Department of Obstetrics and Gynecologic, Faculty of Medicine/ Dr. Mohammad. Hoesin General Hospital, Universitas \\ Sriwijaya, Palembang, Indonesia \\ ${ }^{3}$ Department of Biology, Faculty of Medicine, Universitas Sriwijaya, Palembang, Indonesia
}

\section{A R T I C L E I N F O}

\section{Keywords:}

Vesicovaginal fistule

Parity

Pregnancy

Gynecologic

Obstetrics

\section{*Corresponding author:}

Hadrians Kesuma Putra

\section{E-mail address: \\ hadrianskesuma@fk.unsri.ac.id}

All authors have reviewed and approved the final version of the manuscript.

https://doi.org/10.37275/bsm.v6i3.476

\begin{abstract}
A B S T R A C T
Background. A vesicovaginal fistula (FVV) is a direct pathological connection between the bladder and vagina resulting in uncontrolled leakage of urine into the vagina from the bladder. Based on the cause, fistulas are divided into two, namely obstetric fistula and gynecological fistula. The risk factors that influence the occurrence of FFV consist of obstetric risk factors (age, parity, delivery method, duration of delivery, birth weight) and gynecological risk factors (history of gynecological surgery, history of pelvic radiotherapy, history of gynecologic malignancy). The purpose of this study was to determine the relationship between risk factors and the incidence of vesicovaginal fistula. Methods: This research is an observational-analytic study with a cross-sectional method. The number of samples obtained was 74 patients who met the inclusion criteria using secondary data from medical records. Analysis of the data used is the chi-square test. Results:There were 37 people who experienced vesicovaginal fistula. Where there were 9 patients with obstetric vesicovaginal fistula (24.3\%) and 28 people $(75.7 \%)$. From the Chi-Square test analysis, there was a significant relationship between delivery method $(p=0.029)$, birth weight $(p=0.029)$, history of gynecological surgery $(p=0.038)$, history of pelvic radiotherapy $(p=0.016)$, history of gynecological malignancy $(\mathrm{p}=0.016) .=0.010)$. Meanwhile, there was no significant relationship between age $(p=0,347)$, parity $(p=1,000)$, and duration of labor $(p=0,082)$. Conclusion: There was a significant relationship between the delivery method, birth weight, history of gynecological surgery, history of pelvic radiotherapy, history of gynecological malignancy. There was no significant relationship between age, parity, and duration of vaginal delivery.
\end{abstract}

\section{Introduction}

Vesicovaginal fistula is a direct pathological connection between the bladder and vagina resulting in uncontrolled leakage of urine into the vagina from the bladder. ${ }^{1}$ Based on the cause, fistulas are divided into two, namely obstetric fistula and gynecological fistula. Obstetric fistula is a pathological relationship caused by tissue damage due to obstetric trauma, such as prolonged labor. Gynecological fistulas occur due to complications of gynecological surgery, such as hysterectomy, radiation therapy, malignancy, and congenital abnormalities. 2.3

The incidence of vesicovaginal fistula type obstetric fistula accounts for $84.1 \%-100 \% .^{4}$ In developing countries, the cause of fistula is usually related to 
delivery (>90\%). Based on the 2018 Urological Clinics

of North America Journal, the incidence of vesicovaginal fistula in developed countries ranges from $0.3 \%$ to $2 \%$. Most cases arise because of trauma to the genitourinary tract from pelvic surgery which is usually not recognized during hysterectomy, endometrioma excision, or prolapse surgery. Rare causes of fistulas include radiation injury and advanced pelvic cancer. 5 This study aims to determine the relationship between risk factors and the incidence of vesicovaginal fistula.

\section{Methods}

This type of research is an analytical observational study with a cross-sectional design. The design of this study was to analyze the association of risk factors with the incidence of vesicovaginal fistula. Research and data collection was carried out from October to November 2021 at the Medical Record Installation of Dr. RSUP. Mohammad Hoesin Palembang. The population in this study were all patients who had medical record data at the Obstetrics and Gynecology
Section of Dr. Mohammad Hoesin Palembang in 20182020 .

Samples were collected by the total sampling technique. The sample in this study were patients in the obstetrics and gynecology section of Dr. Mohammad Hoesin Palembang in 2018-2020 who met the inclusion criteria. The inclusion criteria in this study were patients with medical records who had complete risk factor data. All data were collected and then analyzed by univariate and bivariate. The risk factors studied were age, parity, method of delivery, duration of delivery, birth weight, history of gynecological surgery, history of pelvic radiotherapy, and gynecologic malignancy.

\section{Results}

After collecting data, 74 research subjects were obtained, of which 37 patients suffered from vesicovaginal fistula, 9 patients with obstetric vesicovaginal fistula (24.3\%), and 28 patients with gynecological vesicovaginal fistula (75.7\%).

Table 1. Distribution of vesicovaginal fistulas at Dr. Mohammad Hoesin General Palembang in 2018-2020

\begin{tabular}{|c|c|c|}
\hline \multicolumn{1}{|c|}{ Variable } & Amount & Percentage (\%) \\
\hline Vesicovaginal fistula & & \\
\hline Obstetric & 9 & 24.3 \\
\hline Gynecology & & 75.7 \\
\hline Total & & 100.0 \\
\hline
\end{tabular}

Based on the results of the study table 2 shows the relationship of risk factors with the incidence of obstetric vesicovaginal fistula, where risk factors method of delivery ( $p$-value $=0.029$ ) and birth weight $(\mathrm{p}$-value $=0.029)$ had a significant relationship with the incidence of obstetric vesicovaginal fistula. While the risk factors for age $(\mathrm{p}$-value $=0.347)$, parity $(\mathrm{p}$-value $=$ $1,000)$, and duration of labor ( $\mathrm{p}$-value $=0.082) \mathrm{did}$ not have a significant relationship with the incidence of obstetric vesicovaginal fistula in this study. 
Table 2. Relationship between risk factors and obstetrics vesicovaginal fistula at Dr. Mohammad Hoesin General Hospital Palembang in 2018 - 2020

\begin{tabular}{|c|c|c|c|c|c|}
\hline \multirow[t]{2}{*}{ Risk Factors } & \multicolumn{4}{|c|}{ Obstetric Vesicovaginal Fistula } & \multirow[t]{2}{*}{ P-value } \\
\hline & Yes & $\%$ & No & $\%$ & \\
\hline \multicolumn{6}{|l|}{ Age } \\
\hline 20-35 years & 3 & 33.3 & 6 & 66.7 & \multirow[t]{2}{*}{0.347} \\
\hline >35 years & 6 & 66.7 & 3 & 33.3 & \\
\hline Total & 9 & 50.0 & 9 & 50.0 & \\
\hline \multicolumn{6}{|l|}{ Parity } \\
\hline Primiparous & 3 & 50.0 & 3 & 50.0 & \multirow{2}{*}{1,000} \\
\hline Multipara & 6 & 60.0 & 6 & 50.0 & \\
\hline Total & 9 & 50.0 & 9 & 50.0 & \\
\hline \multicolumn{6}{|c|}{ Method of vaginal delivery } \\
\hline Vaginal & 4 & 30,8 & 9 & 69,2 & \multirow[t]{2}{*}{0,029} \\
\hline Caesarean section & 5 & 100,0 & 0 & 0,0 & \\
\hline Total & 9 & 50,0 & 9 & 50 & \\
\hline \multicolumn{6}{|c|}{ Duration of vaginal delivery } \\
\hline$\leq 24$ hours & 5 & 35.7 & 9 & 64.3 & \multirow[t]{2}{*}{0.082} \\
\hline$>24$ hours & 4 & 100.0 & 0 & 0.0 & \\
\hline Total & 9 & 50.0 & 9 & 50.0 & \\
\hline \multicolumn{6}{|l|}{ Birth weight } \\
\hline$\geq 3500$ grams & 5 & 100,0 & 0 & 0.0 & \multirow[t]{3}{*}{0.029} \\
\hline$<3500$ grams & 4 & 30.8 & 9 & 6.0 & \\
\hline Total & 9 & 50.0 & 9 & 50.0 & \\
\hline
\end{tabular}


Based on the results of the study table 3 shows the relationship of risk factors with the incidence of gynecologic vesicovaginal fistula, where risk factors are the history of gynecologic surgery ( $p$-value $=0.038)$, history of pelvic radiotherapy (p-value $=0.016)$, history of gynecological malignancy ( $\mathrm{p}$-value $=0.010)$ had a significant relationship with the incidence of gynecologic vesicovaginal fistula.

Table 3. Relationship between risk factors and the incidence of gynecological vesicovaginal fistula at Dr. Mohammad Hoesin General Palembang in 2018 - 2020

\begin{tabular}{|c|c|c|c|c|c|}
\hline \multirow[t]{2}{*}{ Risk Factors } & \multicolumn{2}{|c|}{$\begin{array}{l}\text { Gynecological } \\
\text { Fistula }\end{array}$} & \multicolumn{2}{|c|}{ Vesicovaginal } & \multirow[t]{2}{*}{ P-value } \\
\hline & Yes & $\%$ & No & $\%$ & \\
\hline \multicolumn{6}{|c|}{ Gynecological Surgery History } \\
\hline Yes & 24 & 60.0 & 16 & 40.0 & \multirow{3}{*}{0.038} \\
\hline No & 4 & 25.0 & 12 & 75.0 & \\
\hline Total & 28 & 50.0 & 28 & 50.0 & \\
\hline \multicolumn{6}{|c|}{ History of Pelvic Radiotherapy } \\
\hline Yes & 3 & 20.0 & 12 & 80.0 & \multirow{3}{*}{0.016} \\
\hline No & 25 & 61.0 & 16 & 39.0 & \\
\hline Total & 28 & 50.0 & 28 & 50.0 & \\
\hline \multicolumn{6}{|c|}{$\begin{array}{l}\text { History of Gynecological } \\
\text { Malignancies }\end{array}$} \\
\hline Yes & 4 & 22.2 & 14 & 77.8 & \multirow[t]{3}{*}{0.010} \\
\hline No & 24 & 63.2 & 14 & 36.8 & \\
\hline Total & 28 & 50.0 & 28 & 50.0 & \\
\hline
\end{tabular}

\section{Discussion}

\section{Age relationship with occurrence of obstetric vesicovaginal fistula}

In this study, the p-value $=0.589$ was obtained. Where in this study could not assess the age factor as a risk factor for fistulas although other studies have previously highlighted young women are more likely to experience fistulas. This is because fistula cases are quite rare and the trend may be different if you have a large number of samples. ${ }^{6}$ 


\section{Parity with obstetric vesicovaginal fistula occurrence}

Based on the results of the chi-square, it is known that the $p$-value is 0.1000 , which means that there is no significant relationship between parity and the incidence of obstetric vesicovaginal fistula. It can be caused by other risk factors. Fistula patients are usually described as primiparous young women with prolonged labor. However, recent studies recognize that obstetric fistula patients are more diverse. Women who are multiparous, undergo multiple peripartum surgeries, and deliver live births are more likely to have a high fistula location. These findings suggest that urological injury during cesarean section or hysterectomy may contribute to fistula formation. ${ }^{7}$

\section{Relationship of method of delivery with occurrence of obstetric vesicovaginal fistula}

Based on the results of chi-square, it is known that the $\mathrm{p}$-value obtained is 0.029 , meaning that there is a significant relationship between the method of delivery and the incidence of obstetric vesicovaginal fistula. This is because fistulas can be caused by cesarean sections in women who arrive late in labor and are operated on by doctors without sufficient experience and using inadequate equipment. However, this can be explained by the difficulty of the operation or the operation of a surgeon who does not have sufficient experience. ${ }^{6}$

\section{The relationship between the duration of vaginal delivery and the incidence of obstetric vesicovaginal fistula}

In this study, a p-value of 0.082 was obtained. the study, there was no significant relationship between duration of labor and vesicovaginal fistula. In developing countries such as northern Nigeria, prolonged labor is caused because access to health facilities is very difficult due to long distances, unavailability of vehicles, and difficult road access. 4 Meanwhile, in South Sumatra, access to health facilities is easier.

\section{Relationship between birth weight and obstetric vesicovaginal fistula}

In this study, a p-value of 0.029 was obtained, which indicates that there is a significant relationship between birth weight and obstetric vesicovaginal fistula occurrence. It is explained that large infants are more likely to cause obstructed labor due to cephalopelvic disproportion in which the soft tissues of the vagina and bladder in pregnant women are compressed between the fetal head and the maternal pelvis by uterine contractions. As the fetal head is forced more and more firmly into the pelvis, the blood supply to the mother's soft tissues is progressively narrowed, and eventually is cut off causing ischemia, the tissue is necrotic and fistula formation occurs. ${ }^{6}$

\section{The relationship between gynecological surgery} history and gynecological vesicovaginal fistula

In this study, a p-value of 0.038 was obtained. There is a significant relationship between the history of gynecological surgery to the incidence of gynecological vesicovaginal fistula. This is because Vesicovaginal fistulas occur in the form of tissue necrosis after tissue ischemia, caused by tissue during surgical procedures or suboptimal placement or use of surgical instruments when dissecting or clamping, or marked inflammation and tissue fibrosis. Later, direct laceration or puncture injury to the urinary tract results in immediate urine leakage. ${ }^{8}$

\section{Relationship of history of pelvic radiotherapy with gynecological vesicovaginal fistula incidence}

In this study, a p-value of 0.016 was obtained. There is a significant relationship between the risk of a history of pelvic radiotherapy on the incidence of vesicovaginal fistula gynecology. This could be because previously irradiated tissue undergoes progressive changes secondary to obliterative endarteritis, which can lead to fibrosis, necrosis, and subsequent fistula formation. 9

\section{The relationship between history of gynecological malignancies and the incidence of gynecological vesicovaginal fistula}

In this study, a p-value of 0.010 was obtained. There is a significant relationship in the history of 
gynecological malignancy with the incidence of gynecologic vesicovaginal fistula. The mechanism for the emergence of urogenital fistula due to malignancy is through direct invasion of cancer into the pelvic area or through cancer metastasis to organs around the pelvis. This causes ischemia and necrosis of the invaded tissue. Pelvic malignancies can spread, especially in the pelvic area, resulting in urogenital fistulas. 10

\section{Conclusion}

The results of the study, there was a significant relationship between method of vaginal delivery and birth weight, history of gynecological surgery, history of pelvic radiotherapy, and history of gynecologic malignancy with the incidence of obstetric vesicovaginal fistula.

\section{References}

1. Kabir M, Iliyasu Z, Abubakar IS, Umar UI, Kabir M. Medico-social problems of patients with vesico-vaginal fistula in murtala Mohammed Specialist Hospital, Kano. Ann Afr Med [Internet]. 2003;2(2):54-7. Available from: https://www.ajol.info/index.php/aam/article /view/8278

2. Hoffman B, Schorge J, Bradshaw K, Halvorson L, Schaffer J, Corton M. Williams gynecology. 3rd ed. McGraw Hill; 2016; 577-589.

3. Prasetyo AT, Sulistiyo A, Suryantara B. Kapita Selecta Urogynecology. I. Pranoto I, Pangastuti $\mathrm{N}$, editors. Yogyakarta: Department of Obstetrics and Gynecology, Faculty of Medicine, UGM/Dr. Sardjito Hospital; 2011. 19-24.

4. Ijaiya M, Rahman A, Aboyeji A, Olatinwo A, Esuga S, Ogah O, et al. Vesicovaginal Fistula: A Review of Nigerian Experience. West Africa $J$ Med. 2011; 29(5).

5. Lee D, Zimmern P. Vaginal Approach to Vesicovaginal Fistula. Urol Clin North Am [Internet]. 2019;46(1):123-33. Available from: https://doi.org/10.1016/j.ucl.2018.08.010

6. Barageine JK, Tumwesigye NM, Byamugisha JK, Almroth L, Faxelid E. Risk factors for obstetric fistula in western Uganda: A case control study. PLOS One. 2014; 9(11).

7. Sih AM, Kopp DM, Tang JH, Rosenberg NE, Chipungu E, Harfouche M, et al. Association between parity and fistula location in women with obstetric fistula: A multivariate regression analysis. BJOG An Int J Obstet Gynaecol. 2016; 123(5): 831-6.

8. Ghoniem GM, Warda HA. The management of genitourinary fistula in the third millennium. Arabic J Urol [Internet]. 2014; 12(2): 97-105. Available from: http://dx.doi.org/10.1016/j.aju.2013.11.006

9. Enemchukwu EA, Brucker BM. Textbook of Female Urology and Urogynecology. Fourth Eddie. Cardozo L, Staskin D, editors. UK: CRC Press; 2017; 1559-1573.

10. Mukti N, Mochtar A, Wiyati P. Incidence of Urogenital Fistula in Women in Dr. Hospital. Kariadi Semarang. Diponegoro Med J (Journal of Medical Doctor Diponegoro). 2018; 7(1): 293-308. 